\title{
Performance of Accounting Sciences Undergraduate Students from High Education Institution of Bahia about the Recent Changes in Financial Statements
}

\author{
Raimundo Nonato Lima Filho, Silvana Lorena Costa Moreira, \\ Ricardo José Rocha Amorim, Francisco Marton Gleuson Pinheiro, \\ Romilson do Carmo Moreira \\ Department of Education, Campus VII, University of State of Bahia, Senhor do Bonfim, Brazil \\ Email: rnlfilho@gmail.com, analo122@hotmail.com, amorim.ricardo@gmail.com, \\ fmarton2003@yahoo.com.br, romilson-moreira@bol.com.br
}

Received 27 February 2015; accepted 10 April 2015; published 15 April 2015

Copyright (C) 2015 by authors and Scientific Research Publishing Inc.

This work is licensed under the Creative Commons Attribution International License (CC BY). http://creativecommons.org/licenses/by/4.0/

(c) (i) Open Access

\begin{abstract}
Accounting in Brazil has experienced changes in legislation, resulting in several changes in the set of financial statements. The objective of this research was to identify the domain of students of Higher Education Institutions (HEIs) in the state of Bahia before the changes caused in the financial statements following the recent Accounting legislation. The methodology adopted in this study was exploratory with a quantitative approach, in which a questionnaire was used as a research tool, composed of 16 statements that addressed the changes in the financial statements on the current Accounting nature legislation. Assertion addressed the major changes in the financial statements. Students participated in the survey of 62 campuses of Bahia IES. 212 responses that did not tend to normality using a Descriptive Statistics with chi-square test were analyzed. Finally, we applied the t-Student Hypothesis Test. The research concluded that the students of Bahian HEIs did not have domain about the changes in the financial statements by Law No. 11,638 (Brazil, 2007) and 11,941 (Brazil, 2009). Therefore, it is believed that this study contributes to awaken Bahian HEIs that have the Accounting course, to assess the need to adopt measures to change the reality reached, the negative performance of their students.
\end{abstract}

\section{Keywords}

Accounting Rules, Financial Statements, Area, High Education Institution 


\section{Introduction}

The Corporate Accounting in Brazil has and continues to go through transformation processes guided by Accounting rules. With the enactment of Law No. 11,638 (Brazil, 2007) known as the New Corporate Law this was no different. This law amended, revoked and introduced new provisions to Law 6404 (Brazil, 1976), Corporate Law, in which the emphasis in this research is intended to changes in the financial statements, as well as performance analysis of the course students of Accounting in Higher Education Institutions (HEIs) in the state of Bahia.

Law 11,638 (Brazil, 2007) had as its main purpose to reconcile Brazilian Accounting practices with international practice. With the development of markets there was a need to promote transparency in financial statements so as to allow understanding of the likely national and international investors. Thus, this law was essential in Brazil for the convergence of international Brazilian Accounting practices and changed the Financial Statements, reformulating them.

According to the New Law of Corporations, at the end of each fiscal year the board of the entity is in charge of drawing up the following financial statements: the Income Statement (DRE), Balance Sheet (BP), Profit and Loss or Losses (DLPA), Statement of Changes in Shareholders' Equity (DMPL), Cash Flow Statement (DFC), and when the company is opened, the Statement of Value Added (DVA). In addition to adding new statements, the law has changed the structure of existing financial statements, primarily the BP and the DRE.

Subsequently, the law in question was amended by Provisional Measure 449 of 2008 and, together with other standards, transformed into Law 11,941 (Brazil, 2009). The changes and additions transferred to the Financial Statements whose applicable law taken as a basis, was the Law 11,638 (Brazil, 2007), are used to this day by Accounting professionals.

In 2004, the Ministry of Education (MEC), through the National Education Council (CNE) and the Board of Higher Education (CES), supported the National Curriculum Guidelines for graduate courses in which changed the text of Resolution CNE/CES No. 06 (Brazil, 2004). Specifically in the Accounting course, the CNE and the ETUC addressed the Essential Skills and Abilities for the training of Accounting professionals. Among other things, it is for the Accounting professional future know how to build effective advice and reports to users involved, regardless of the model addressed by the organization, and be aware of how to properly apply the existing legislation to the required Accounting functions.

According to Peleias (2006), it is essential to future Accounting professionals passing through a good education. That's because this is the best path for them to identify opportunities and threats to their employability. In this sense, it is necessary that these professionals know how to prepare advice in accordance with current legislation and that they are able to face the possible challenges to be found.

After a study in a Federal Institution of Paraíba state of higher education, whose aim was to identify the perception of students in Accounting before the academic training received by them, Santos et al. (2014) concluded that these students, mostly disagree that are acquiring sufficient knowledge to enter and operate in the labor market.

Paradoxically, in a survey conducted by Espejo et al. (2010) aimed to assess the knowledge of students in a higher education institution in the state of Paraná on the main changes in the financial statements after Law 11,638 (Brazil, 2007), the authors found that students had knowledge domain.

In this way, this article is guided by the following problem: The students of Accounting Course of Higher Education Institutions in Bahia dominate the changes in the Financial Statements after the promulgation of the Law 11,638/07 and 11,941/09?

This study is justified by the essentiality of the students in Accounting dominate the structures of Financial Statements force. Moreover, it is remarkable that there is a lack of research focused simultaneously on all of the existing financial statements and the domain of students on these changes.

\section{Theoretical Framework}

According to Ribeiro (2009), the financial statements are crucial tools for any company. However, for these statements to be really useful, it is essential that the makers deeply know the structure of each one of it so that they can be built effectively. The author argues that the Accounting student must have a Satisfactory education that contributes to transform him into a good professional.

The National Proposal Content for the Course of Accounting, admitted by the CFC and supported by the Bra- 
zilian Accounting Foundation (BCF) in 2009 (Accounting Federal Council, 2009) aims to harmonize the teaching in terms of content. In this proposal, the inclusion of components was suggested for the course curriculum in Accounting in the university in Brazil. Thus, the "Structure of Financial Statements", which includes all current Financial Statements, is a basic curriculum component for the formation of professional Accounting.

Under the chapeau of Article 176 of Law 6404 (Brazil, 1976), the board of a company had a duty to draw up four financial statements that clearly express the entity patrimony situation: I) Balance Sheet (BP); II) the Income Statement (DRE); III) Statement of Changes in Financial Position (DONATE); and finally IV) Statement of Profit or Loss Collected (DLPA). According to this law, DLPA may be included in the Statement of Changes in Shareholders' Equity (DMPL) if this statement is drawn up and published by the company.

The New Corporate Law replaced the Funds by the Cash Flow Statement (DFC) added a new demonstration for public companies entities, the Statement of Value Added (DVA), and modified some accounts of other statements. Cardoso et al. (2009) assume that the replacement of the Funds by DFC and the creation of DVA came to meet the desires of the users of Accounting information, as listed companies would automatically to show the DFC and the DVA.

With Law 11,941 (Brazil, 2009) any financial statements was created or replaced. However, some statements of account groups have undergone changes.

According to Iudícibus (2007), the BP is a kind of demonstration that reflects the balance sheet in a given period of time, most commonly a period of one year. For Marion (2009), the BP is the main demonstration, because it reflects the actual financial position of the company in a given period of time.

The division of assets and liabilities in current and non-current, caused by the New Corporation Law, facilitated the analysis of the financial position of the entity. This is because this segregation allows to know basic information, such as the ability of the company has to settle its obligations (Cunha \& Lima, 2011).

According to Marion (2009), for something to be considered active is essential that follow four characteristics simultaneously: 1) needs to be good or right; 2) must be owned by the company, without exception; 3) it must be measurable in money; and finally, 4) is essential to bring any present or future benefit to the entity.

According to Art. 178, § 1 of Law 6404 (Brazil, 1976), Active was subdivided into three groups: 1) Assets; 2) Assets to Long Term; and 3) Permanent assets. The latter being composed of three subgroups: 1) Investments; 2) Fixed Assets; and 3) Deferred Charges.

Law 11,638 (Brazil, 2007) included the "Intangible assets" group accounts in Fixed Assets. Finally, Law 11,941 (Brazil, 2009), the groups that form the active, has last modification, would exist only: 1) Current assets and 2) Non-current assets. The latter was subdivided into four other groups: 1) Assets long-term; 2) Investments; 3) Property; and 4) Intangible assets. This is the structure used today.

According Lima Filho and Bruni (2012), even though the importance of the concept of assets, is the common teaching of this definition as merely a "set of assets and rights" or an "application" feature, there are no discussions about it.

According Velter and Missagia (2007), the passive is, among other information, all obligations of the entity. This term can indicate both the deferred income, with inclusion of shareholders' equity, as stated in the current legislation; as indicate their natural sense in which only considers Equity group share, and not as an extension of liabilities. In this research, Equity was treated as a separate group of liabilities.

According to Article 178, § 2, of Law 6404 (Brazil, 1976), the passive account is a group divided into four other groups: 1) Current liabilities or liabilities; 2) Liabilities Long-term liabilities; 3) Deferred income; and 4) Net Equity. Because of the changes brought about by Law No. 11,941 (Brazil, 2009), the passive began to include the following groups: 1) Current liabilities; 2) Non-current liabilities; and 3) Equity.

Velter and Missagia (2007) define Net Equity as the result of the difference between the active and the passive. Because of this, Net Equity can also be known as Own Capital. It should be noted that this account group does not represent any obligation on members of the company, because not acquired entity loans, and yes, have joined forces to achieve a common goal.

The Corporate Law subdivided Net Equity in five small groups: 1) Capital; 2) Capital reserves; 3) Revaluation reserves; 4) Profit reserves; and 5) Retained earnings.

Law 11,638 (Brazil, 2007) changed and added Net Equity groups. This came to be composed of six subgroups: 1) Capital; 2) Capital reserves; 3) Asset valuation adjustment; 4) Profit reserves; 5) Treasury shares; and 6) Losses.

As Iudícibus (2007) argue, the DRE, in turn, is a report informing the end result of a fiscal year, indicating 
whether the company made a profit or loss. For this, the expenses are subtracted from revenues.

After Law 11,941 (Brazil, 2009), the DRE started to discriminate: gross revenue, removing rebates and taxes on sales; net revenue, absent the cost value of sold goods and services, resulting in gross profit; revenues and operating expenses, and other income and expenses, generating operating profit or loss; non-operating revenues and expenses; the result for the year before Income Tax and the provision for the same tax; the holdings of debentures, employees, managers and shares; Finally, the net income or loss for the year and the amount per share of the social capital.

Created after Law 11,638 (Brazil, 2007), VAD seeks to demonstrate the wealth generated and distributed by the companies, making it useful in the macroeconomic scenario, since it involves many groups in society, such as the government, customers and partners (Berns \& Flach, 2013).

VAD not only demonstrates the wealth generated by the company, also reports: the benefits offered by the entities to society; the identification of wealth received by transfer; and a breakdown of how wealth is distributed among the beneficiaries (Cunha, Ribeiro, \& Santos, 2005).

As Ribeiro (2009), DLPA is a kind of report whose main purpose is to highlight the fate of net income that was calculated at the end of the fiscal year.

According to Art. 186, paragraph 2 of Law No. 6404 (Brazil, 1976), DLPA may be included in the Statement of Changes in Shareholders' Equity (DMPL) if prepared by the entity. In addition, entities are DISCLAIMED to develop DLPA they come to DMPL. This is because the DMPL incorporates all the information in the DLPA.

Substitute the DONATE after Law 11,638 (Brazil, 2007), the DFC is responsible to show all existing transactions in a given period of time in which caused changes in the cash account balance (Ribeiro, 2009). Ferreira (2009) is not as restricted, reports that the DFC highlights the changes in the availability of an entity during a given fiscal year.

Rose and Faria (2010) point out that, after the changes introduced by New Corporation Law, all companies closed whose Equity is less than US \$ 2 million will not be required to prepare the DFC.

According to Law No. 11,638 (Brazil, 2007), the DFC indicate segregated the changes in cash and cash equivalents, in at least three streams: 1) Cash flow from operations; 2) Funding flows; and 3) Cash flow from investments.

The DFC has two possible methods: direct and indirect. Informs that the first considers the inputs and outputs to the corresponding gross operations. But the indirect method consists of the present balance in the income statement. This statement aims to highlight the changes in the accounts that are part of shareholders' equity in a given period of time. It is appropriate to say that the DMPL enables get a clear indication of flow from one account to another, indicating the origin and the reduction in value or additions in the accounts Net Equity (Ribeiro, 2009).

Note that the DMPL is more comprehensive than the DLPA, it shows the changes in Net Equity accounts during the year, including the account that DLPA states: Retained earnings.

Rose and Faria (2010) point out that, due to the requirement of the Securities and Exchange Commission (CVM), public companies are required to prepare, in addition to the mandatory statements, DMPL. However, it is optional to other companies.

Given the above, the following section will address the methodological procedures.

\section{Methodological Procedures}

As for the overall goal, this research is classified as exploratory. To Gil (2002), this type of research seeks to approach the problem in order to make it lighter or build hypotheses. As for the technical procedures, this study used a questionnaire. According to Lakatos and Marconi (1992), this technique consists of questions in which respondents must answer them without the presence of the researcher. Regarding the problem, this research is a quantitative analysis. According to Raupp and Beuren (2013), the quantitative approach uses statistical tools in data processing.

This research examined students from public and private HEIs, located in the state of Bahia, and recognized by the Ministry of Education (MEC). To identify and select the HEIs, a responsible electronic system was used, among other functions, to monitor the processes that regulate higher education in Brazil and the recognition of courses: the e-MEC.

Through the e-MEC site was possible to identify all Bahian HEIs, totaling 55. However, due to lack of contact with an HEI, only 54 were selected. In due course, it is necessary to clarify that the various campuses of the same 
HEI were considered individually. Thus, the number of participants amounted to 62 campuses HEI undergraduate degree in Accounting from suppliers in 25 municipalities in Bahia. In total, 54 from private and 8 from public campuses.

\subsection{Research Tool}

In the present study we used a questionnaire designed specifically (see Appendix). This measure showed an average of three assertions for each Accounting statement, in which the respondent judged them and chose the option to consider most appropriate.

The questionnaire was based on conceptual understanding of the subjects covered, disregarding any statement that required calculation to solve it. Assertive addressed the changes in the statements brought about by legislation, correlating the existing statements with the same before the changes.

\subsection{Event}

To assist questions of the research, we proposed a hypothesis, represented by H1.

The H1 states that the students of Bahia higher education institutions dominate the changes in the financial statements after the enactment of Law No. 11,638 (Brazil, 2007) and 11,941 (Brazil, 2009).

The hypothesis is settled in the study by Espejo (2010), which concluded that students of a certain area on the IES have caused changes in the New Corporation Law.

After the application of specific tests and, consequently, to obtain the results of this research, the above hypothesis is accepted or rejected.

\subsection{Analysis Plan}

Before analysis, the data from this study underwent a preparation. Initially, we tested the normality of the sample to check whether followed a normal distribution.

We analyze also the set of answers, excluding the performance of individual students. The responses of the statements were organized into three groups: "Satisfactory", corresponding to the assertions that are answered correctly; "Unsatisfactory" for the incorrectly answered assertive; and "Do not know or do not know the demonstration", giving the respondent the option of not responding or admit they do not know the subject matter. Therefore, first, the absolute frequency (Fi) and the relative frequency percentage (Fi\%) of all sample was found.

After setting the frequency of responses, we have considered the chi-square test, used when there is interest in checking whether the observed frequencies are significantly different from an expected set of frequencies, as Barbetta, Kings and Bornia (2010).

Finally, the Hypothesis t-Student test was carried out. According to Callegari-Jacques (2003), the hypothesis test is a statistical procedure whose function is to reject or not a particular case, considering a risk of error. The author concludes by arguing that the tested hypothesis is always the null hypothesis (H0). If this is rejected, the alternative hypothesis (H1) is automatically accepted. In this context, the t-Student test uses statistical concepts to reject or not to $\mathrm{H} 0$.

For all the statistical analysis used in this study, we used the Statistical Package for Social Sciences software for Windows (SPSS) version 21, which allowed for complex calculations, as well as simplified view of your results.

Given these procedures, broke for the analysis and discussion of the data.

\section{Data Analysis and Discussion of Results}

The sample obtained through the questionnaire applied in Bahia HEIs totaled 212 responses. To test the normality of the sample held the normality tests the Kolmogorov-Smirnov and the Shapiro-Wilk, originating in Table 1.

We opted for the Kolmogorov-Smirnov test with Lilliefors correction, because the sample was greater than 20 . The result of Normality Test showed $0 \%$ Sig. in all the statements, that is, below the level of significance of 5\%, usually statistically adopted. The rejection of the null hypothesis (H0) of the normal distribution of data was corroborated. Therefore, the data of this research tend not normal. 
Table 1. Normality test.

\begin{tabular}{|c|c|c|c|c|c|c|c|}
\hline & & \multicolumn{3}{|c|}{ Kolmogorov-Smirnov ${ }^{\mathrm{a}}$} & \multicolumn{3}{|c|}{ Shapiro-Wilk } \\
\hline & & Statistics & $\mathrm{DF}$ & Sig. & Statistics & $\mathrm{DF}$ & Sig. \\
\hline \multirow{3}{*}{ BP } & $\mathrm{A} 1$ & 0.352 & 212 & 0.000 & 0.719 & 212 & 0.000 \\
\hline & A2 & 0.368 & 212 & 0.000 & 0.704 & 212 & 0.000 \\
\hline & A3 & 0.254 & 212 & 0.000 & 0.801 & 212 & 0.000 \\
\hline \multirow{3}{*}{ DRE } & A4 & 0.367 & 212 & 0.000 & 0.700 & 212 & 0.000 \\
\hline & A5 & 0.238 & 212 & 0.000 & 0.794 & 212 & 0.000 \\
\hline & A6 & 0.292 & 212 & 0.000 & 0.789 & 212 & 0.000 \\
\hline \multirow{3}{*}{ DVA } & A7 & 0.293 & 212 & 0.000 & 0.763 & 212 & 0.000 \\
\hline & A8 & 0.326 & 212 & 0.000 & 0.735 & 212 & 0.000 \\
\hline & A9 & 0.346 & 212 & 0.000 & 0.727 & 212 & 0.000 \\
\hline \multirow{2}{*}{ DLPA } & A10 & 0.321 & 212 & 0.000 & 0.687 & 212 & 0.000 \\
\hline & A11 & 0.378 & 212 & 0.000 & 0.686 & 212 & 0.000 \\
\hline \multirow{3}{*}{ DFC } & A12 & 0.329 & 212 & 0.000 & 0.686 & 212 & 0.000 \\
\hline & A13 & 0.354 & 212 & 0.000 & 0.714 & 212 & 0.000 \\
\hline & A14 & 0.292 & 212 & 0.000 & 0.773 & 212 & 0.000 \\
\hline \multirow{2}{*}{ DMPL } & A15 & 0.270 & 212 & 0.000 & 0.778 & 212 & 0.000 \\
\hline & A16 & 0.317 & 212 & 0.000 & 0.755 & 212 & 0.000 \\
\hline
\end{tabular}

Note: Own elaboration (2015). ${ }^{\mathrm{a}}$ Lilliefors meaning correction.

Later, there was a Descriptive Statistics with chi-square, organizing the data into a frequency distribution. According Barbetta, Kings and Bornia (2010), distribute the data following a frequency is important to analyze them, especially when the sample is large.

In this research, for the respondent's domain analysis was considered only two groups, the "Satisfactory" and "Unsatisfactory". Thus, it was not considered responses equivalent to "do not know or do not know the demonstration" as incorrect.

The sample was analyzed in two steps. At first, it was observed assertive powers of each Accounting Statement. Subsequently, a performance analysis of students in each demonstration was held.

\subsection{Analysis Statement}

Sample analysis was organized into topics, each representing a specific demonstration. The responses were analyzed following the absolute frequencies and relative in percentage and the results of the chi-square test.

In all the statements, except for the A5, there was discrepancy between the observed and expected frequencies. Along with this, the Sig. was below the 5\% threshold, allowing generalize the result of the sample to the population following a security level of $95 \%$. The values of the chi-square test and frequencies were detailed in tables.

\subsubsection{Balance Sheet (BP)}

As Table 2, the chi-square of the statements was high, reaching an average of 50.151. This implies that the distance between observed and expected frequencies was large, the absence of adhesion. Thus, it is unlikely that all these variations have followed a fluke. In the statements, the value of Sig. was less than $5 \%$, indicating that there are statistically significant differences in the responses.

Table 2 establishes that the assertions A1 and A2 the Unsatisfactory results highlighted. The predominance of Unsatisfactory results in the assertion A1 draws attention because the questioning have involved an account that is not set in the BP Corporation and large companies subject to Law 6404 (Brazil, 1976). Currently this account 
Table 2. Results of answers regarding the balance sheet.

\begin{tabular}{|c|c|c|c|}
\hline & \multicolumn{2}{|c|}{ Total } & \multirow{2}{*}{$\begin{array}{c}\text { Chi-square } \\
\text { Dif } \\
\text { Sig }\end{array}$} \\
\hline & $\mathrm{Fi}$ & $\mathrm{Fi} \%$ & \\
\hline \multicolumn{4}{|l|}{ A1 } \\
\hline Satisfactory & 52 & $24.50 \%$ & 52.679 \\
\hline Unsatisfactory & 120 & $56.60 \%$ & 2 \\
\hline Do not know or do not know the demonstration & 40 & $28.90 \%$ & 0.000 \\
\hline \multicolumn{4}{|l|}{ A2 } \\
\hline Satisfactory & 53 & $25.00 \%$ & 67.821 \\
\hline Unsatisfactory & 126 & $59.40 \%$ & 2 \\
\hline Do not know or do not know the demonstration & 33 & $15.60 \%$ & 0.000 \\
\hline \multicolumn{4}{|l|}{ A3 } \\
\hline Satisfactory & 104 & $49.10 \%$ & 29.953 \\
\hline Unsatisfactory & 39 & $18.40 \%$ & 2 \\
\hline Do not know or do not know the demonstration & 69 & $32.50 \%$ & 0.000 \\
\hline
\end{tabular}

Note: Own elaboration (2015).

was removed from the statement by Law 11,638/07: profits and accumulated losses. Probably the justification of the negative result in the assertion A2 is because the question addressed a more recent change, brought by Law 11,941 (Brazil, 2009), the inclusion of "Long-term" subgroup in the Non-Current Assets group.

On the A3, one can see that the result was reversed, there was more Satisfactory answers. In contrast, students who have chosen index does not respond to questioning was the largest of the three. The statement addressed the subgroups for the equity, which was no change after Law 11,638 (Brazil, 2007).

Overall, Unsatisfactory results predominated, representing approximately $44.81 \%$ of the responses. Thus, it is inferred that the students of Bahian IES not dominate the changes in BP after the Law 11.638/07 and 11.941/09.

\subsubsection{The Income Statement (DRE)}

It is observed from Table 3 that the value of chi-square in assertive A5 showed a very low reference, i.e., the observed frequency does not differ statistically from the expected frequency, tending to chance variations. Another factor to note is the value of Sig. [42.60\%], well above the level of significance 5\% limit. Thus, it is incorrect to state that there is a statistical difference between the results. Therefore, to conclude that the frequency Satisfactory is statistically superior to Unsatisfactory, the probability of error reaches $42.60 \%$. Thus, especially for this assertion, the result will be disregarded in the analysis because it has no statistical significance.

As for assertions A4 and A6, it is noticeable that the chi-square values were high, reaching an average of 57.887. With this, it means that the distance between observed and expected frequencies was large. Soon, there is no grip, which reduces the possibility of variations found they followed a fluke. Coupled to this, the value of Sig. [0\%] corroborates statistical difference in the responses of the statements.

As Table 3 shows, the assertive A4 frequency of Unsatisfactory prevailed, coming to meet almost $60 \%$ of the total sample. However, the opposite occurred on the A6, the result Satisfactory prevailed, equivalent more than triple the Unsatisfactory results.

Both assertions addressed the DRE of the structure and the nomenclature used. However, the results obtained in assertive A4 and A6 were opposed. Probably, this contradiction occurred because the nomenclature used in assertive A4 was closer to that adopted in the legislation. In the statement A6, the terminology adopted was simple "direct sales tax," "sold goods returns" and "rebates on sales."

Only the separate performance of students in the statements A4 and A6 not allow for a definitive conclusion. 
Table 3. Results of answers relating to the income statement.

\begin{tabular}{|c|c|c|c|}
\hline & \multicolumn{2}{|c|}{ Total } & \multirow{2}{*}{$\begin{array}{c}\text { Chi-square } \\
\text { Dif } \\
\text { Sig. }\end{array}$} \\
\hline & $\mathrm{Fi}$ & $\mathrm{Fi} \%$ & \\
\hline \multicolumn{4}{|l|}{ A4 } \\
\hline Satisfactory & 44 & $20.80 \%$ & 62.670 \\
\hline Unsatisfactory & 125 & $59.00 \%$ & 2 \\
\hline Do not know or do not know the demonstration & 43 & $20.30 \%$ & 0.000 \\
\hline \multicolumn{4}{|l|}{ A5 } \\
\hline Satisfactory & 73 & $34.40 \%$ & 1.708 \\
\hline Unsatisfactory & 62 & $29.20 \%$ & 2 \\
\hline Do not know or do not know the demonstration & 77 & $36.30 \%$ & 0.426 \\
\hline \multicolumn{4}{|l|}{ A6 } \\
\hline Satisfactory & 118 & $55.70 \%$ & 53.104 \\
\hline Unsatisfactory & 33 & $15.60 \%$ & 2 \\
\hline Do not know or do not know the demonstration & 61 & $28.80 \%$ & 0.000 \\
\hline
\end{tabular}

Note: Own Elaboration (2015).

For there was the result opposition between these assertions, while not exist statistical significance of the result obtained in assertive A5. Thus, even analyzing the result as a whole is well known that the Satisfactory group [38.21\%] no statistical difference in the Poor [37.26\%].

\subsubsection{Statement of Value Added (DVA)}

According to Table 4, all of the statements presented higher the value of chi-square, around 44.179. Thus, the distance between observed and expected frequencies tends to be high, the absence of adhesion. Therefore, the variations found in the results probably were not random. The significance level below the $5 \%$ threshold, the three assertions, reinforces that there is a statistical difference in the responses.

Table 4 provides that the assertions A7 and A9 frequency regarding the Satisfactory prevailed. The assertive A7 was merely the function of DVA, requiring a basic knowledge of the statement. Already the A9, addressed the demonstration structure. As the National Proposal Content for the Undergraduate Program in Accounting 2009, conceptual aspects, training and the distribution of wealth are basic contents about the DVA. Therefore possibly predominated Satisfactory group in the statements mentioned as they dealt with general issues.

As for the A8, it was noticed that the Unsatisfactory results prevailed. Referring to the questionnaire, we see the statement required that the respondent possessed greater knowledge of the entire structure of the DVA.

It is observed that the number of students who chose not to respond was quite high in all assertions. Probably, this fact is justified by the DVA has been created after the New Corporation Law, recent being the existence of the required statement for the public companies companies.

In general, the result was superior to Unsatisfactory Satisfactory, $30.97 \%$ and $18.08 \%$, respectively. Thus, it is clear that the students of higher education institutions in the state of Bahia have power about the DVA.

\subsubsection{Statement of Profits and Losses (DLPA)}

As Table 5, it is clear that the chi-square values are quite high, resulting in the highest average among the statements [65.939]. This implies the high distance between the observed and expected frequencies. Therefore, there is no grip between responses, allowing these variations tend not to chance. The values of the Sig. the assertions were below the $5 \%$ threshold, thus the answers present statistical difference.

As shown in Table 5, the highlight was the result Unsatisfactory. Noteworthy is the difference between Sa- 
Table 4. Results of answers regarding the statement of value added.

\begin{tabular}{|c|c|c|c|}
\hline & \multicolumn{2}{|c|}{ Total } & \multirow{2}{*}{$\begin{array}{c}\text { Chi-square } \\
\text { Dif } \\
\text { Sig. }\end{array}$} \\
\hline & $\mathrm{Fi}$ & $\mathrm{Fi} \%$ & \\
\hline \multicolumn{4}{|l|}{ A7 } \\
\hline Satisfactory & 93 & $43.90 \%$ & 50.387 \\
\hline Unsatisfactory & 22 & $10.40 \%$ & 2 \\
\hline Do not know or do not know the demonstration & 97 & $45.80 \%$ & 0.000 \\
\hline \multicolumn{4}{|l|}{ A8 } \\
\hline Satisfactory & 47 & $22.20 \%$ & 31.764 \\
\hline Unsatisfactory & 56 & $26.40 \%$ & 2 \\
\hline Do not know or do not know the demonstration & 109 & $51.40 \%$ & 0.000 \\
\hline \multicolumn{4}{|l|}{ A9 } \\
\hline Satisfactory & 57 & $26.90 \%$ & 50.387 \\
\hline Unsatisfactory & 37 & $17.50 \%$ & 2 \\
\hline Do not know or do not know the demonstration & 118 & $55.70 \%$ & 0.000 \\
\hline
\end{tabular}

Note: Own Elaboration (2015).

Table 5. Results of responses related to the statement of profit and losses.

\begin{tabular}{|c|c|c|c|}
\hline & \multicolumn{2}{|c|}{ Total } & \multirow{2}{*}{$\begin{array}{c}\text { Chi-square } \\
\text { Dif } \\
\text { Sig. }\end{array}$} \\
\hline & $\mathrm{Fi}$ & $\mathrm{Fi} \%$ & \\
\hline \multicolumn{4}{|l|}{ A10 } \\
\hline Satisfactory & 18 & $8.50 \%$ & 59.585 \\
\hline Unsatisfactory & 92 & $43.40 \%$ & 2 \\
\hline Do not know or do not know the demonstration & 102 & $48.10 \%$ & 0.000 \\
\hline \multicolumn{4}{|l|}{ A11 } \\
\hline Satisfactory & 40 & $18.90 \%$ & 72.292 \\
\hline Unsatisfactory & 43 & $20.30 \%$ & 2 \\
\hline Do not know or do not know the demonstration & 129 & $60.80 \%$ & 0.000 \\
\hline
\end{tabular}

Note: Own Elaboration (2015).

tisfactory and Unsatisfactory assertive the A10, which is equivalent to $34.90 \%$ percentage points. This result is alarming, because the statement was treated regarding an important relationship of DLPA with DMPL, which is provided for in the Corporation Law and suffered subsequent amendment.

Although small, the assertive A11 was more often Unsatisfactory group. The statement in question was more specific, requiring greater knowledge of students about the statement.

It should be noted the high frequency of students who chose not to answer the statements. Possibly justified what happened because of little use in practice this statement, since it is not legally binding for companies preparing to DMPL, so be little taught in HEIs.

It follows that the students of Bahian IES not dominate the subject matter on the DLPA. In general, Unsatisfactory group corresponds to $31.84 \%$, i.e. $18.16 \%$ percentage points higher than Satisfactory group [13.68\%]. 


\subsubsection{Statement of Cash Flows (DFC)}

Observing Table 6, we note that the statements have a value of high chi-square, around 47.302. Therefore the distance between observed and expected frequencies tends to be large, resulting in that no grip. Thus, it is unlikely that variations of the answers have followed a fluke. In addition, it is noteworthy that the Sig. the three assertions were less than $5 \%$, indicating a statistically significant difference in the responses.

In analyzing the responses for the DFC, it is clear that the result was balanced. We can see the contrast between the A12 and A14 assertive. While in the first (A12), almost 50\% of respondents had Unsatisfactory result, in the second (A14), prevailed the results Satisfactory. Finally, it is observed that the A13, the result between Satisfactory and Unsatisfactory was the same, that is, it was not possible to say whether or not mastery over the subject matter.

The A12 and A13 assertive demanded more attention respondent because the resolution of both depended on the small expressions adopted. Note that the assertion A14 there was a higher prevalence of Satisfactory result. However, the rate of students who do not know or do not know the proof is high. This result is justified, probably because it is a statement that involves both general and specific understandings of the methods of CFD.

Analyzing individual assertive way, it was not possible to confirm whether respondents had field before the DFC, as there was a balance in the overall result, in which the Satisfactory stood out on the A14, the poor in A12, and A13 not predominated between Satisfactory and Unsatisfactory. However, overall, it was noticed that the students of Bahian IES not dominate the DFC, since the percentage of the Poor [29.25\%] is greater than Satisfactory [22.48\%].

\subsubsection{Statement of Changes in Shareholders' Equity (DMPL)}

According to Table 7, the responses of the statements obtained high values of chi-square, being the average of 37.397. Thus, the distance between observed and expected frequencies tend to have been high, the absence of adhesion, i.e., it is unlikely that there chance variations in the responses. It is clear that the Sig. the two assertions were $0 \%$, below the $5 \%$ threshold. Hence, the answers differ statistically.

In both assertions, it is noticed that the Satisfactory prevailed. While the assertion of A15 treated DMPL main function of the A16 investigated the relationship between the DLPA and DMPL. So probably the Satisfactory outcome prevailed because the topics discussed are provided in the legislation since the Corporate Law 1976, which did not undergo subsequent amendments.

Table 6. Results of the answers relating to the cash flow statement.

\begin{tabular}{|c|c|c|c|}
\hline & \multicolumn{2}{|c|}{ Total } & \multirow{2}{*}{$\begin{array}{c}\text { Chi-square } \\
\text { Dif } \\
\text { Sig. }\end{array}$} \\
\hline & $\mathrm{Fi}$ & $\mathrm{Fi} \%$ & \\
\hline \multicolumn{4}{|l|}{ A12 } \\
\hline Satisfactory & 18 & $8.50 \%$ & 60.689 \\
\hline Unsatisfactory & 105 & $49.50 \%$ & 2 \\
\hline Do not know or do not know the demonstration & 89 & $42.00 \%$ & 0.000 \\
\hline \multicolumn{4}{|l|}{ A13 } \\
\hline Satisfactory & 46 & $21.70 \%$ & 51.660 \\
\hline Unsatisfactory & 46 & $21.70 \%$ & 2 \\
\hline Do not know or do not know the demonstration & 120 & $56.60 \%$ & 0.000 \\
\hline \multicolumn{4}{|l|}{ A14 } \\
\hline Satisfactory & 79 & $37.30 \%$ & 29.557 \\
\hline Unsatisfactory & 35 & $16.50 \%$ & 2 \\
\hline Do not know or do not know the demonstration & 98 & $46.20 \%$ & 0.000 \\
\hline
\end{tabular}

Note: Own Elaboration (2015). 
Table 7. Results of answers regarding the statement of changes in Net Equity.

\begin{tabular}{|c|c|c|c|}
\hline & \multicolumn{2}{|c|}{ Total } & \multirow{2}{*}{$\begin{array}{c}\text { Chi-square } \\
\text { Dif } \\
\text { Sig. }\end{array}$} \\
\hline & $\mathrm{Fi}$ & $\mathrm{Fi} \%$ & \\
\hline \multicolumn{4}{|l|}{ A15 } \\
\hline Satisfactory & 96 & $45.30 \%$ & 40.821 \\
\hline Unsatisfactory & 27 & $12.70 \%$ & 2 \\
\hline Do not know or do not know the demonstration & 89 & $42.00 \%$ & 0.000 \\
\hline \multicolumn{4}{|l|}{ A16 } \\
\hline Satisfactory & 67 & $31.60 \%$ & 33.972 \\
\hline Unsatisfactory & 38 & $17.90 \%$ & 2 \\
\hline Do not know or do not know the demonstration & 107 & $50.50 \%$ & 0.000 \\
\hline
\end{tabular}

Note: Own Elaboration (2015).

It is observed in the statements the high rate of students who do not know or do not know the demonstration, equivalent to $46.23 \%$ overall. Possibly this happened DMPL be a little used demonstrative, as it is required only to publicly traded entities, being optional to the other companies.

Analyzing the overall result, we note that the result Satisfactory [38.44\%] is greater than the Poor [15.33\%]. In short, it is noticeable that the students of Higher Education Institutions in Bahia dominate DMPL.

\subsection{Test Event}

As mentioned above, we used the Student t test hypothesis to reject or not to H0. The test was conducted based on the following assumptions:

H0: Establishes that students of Bahian higher education institutions dominate the changes in the financial statements after the enactment of Law No. 11,638 (Brazil, 2007) and 11,941 (Brazil, 2009).

H1: Establishes that students of higher education institutions Bahian not dominate the changes in the financial statements after the enactment of Law No. 11,638 (Brazil, 2007) and 11,941 (Brazil, 2009). The result of applying the hypothesis t test-Student is shown in Table 8 . It is observed that in all the statements Sig. was $0 \%$, that is, the responses indicated the rejection of the null hypothesis H0. Therefore, the students of higher education institutions in the state of Bahia not dominate the changes in the financial statements after the promulgation of Laws 11,638/07 and 11,941/09.

Analyzing the domain of students in each statement, it is noticeable that the result in three is Unsatisfactory prevailed in BP, in DLPA and DFC. Only two financial statements the result was higher than Satisfactory Unsatisfactory in DVA and DMPL. The result for the DRE was inconclusive because there was no statistical difference in the responses. Thus, it reinforces the result obtained by the hypothesis test, because Unsatisfactory answers predominated.

It was noted that when the students were faced with questions that required a deeper knowledge about the current financial statements, the difference between Unsatisfactory and Satisfactory answers was even higher.

\section{Conclusion}

This study aimed to identify the domain of students of Higher Education Institutions (HEIs) in the State of Bahia on the changes that the Laws 11,638/07 (Brazil, 2007) and 11,941 (Brazil, 2009) caused in the Financial Statements.

For this, we developed an own collection instrument. 16 assertions were prepared based on Law No. 6404 (Brazil, 1976) and recent changes in which the respondents judged and opted for the alternative that was closest to his understanding addressed before the demonstration.

The sample was composed of 212 respondents. In the analysis initially applied the Normality Test to check if 
Table 8. Nonparametric test (t-Student).

\begin{tabular}{|c|c|c|}
\hline Analysis categories & $\mathrm{t}$ & Sig. (bi-caudal) \\
\hline \multicolumn{3}{|c|}{ Balance sheet (BS) } \\
\hline Assertive 1 & 11.558 & 0.000 \\
\hline Assertive 2 & 10.920 & 0.000 \\
\hline Assertive 3 & 23.702 & 0.000 \\
\hline \multicolumn{3}{|c|}{ The Income Statement (DRE) } \\
\hline Assertive 4 & 11.110 & 0.000 \\
\hline Assertive 5 & 19.282 & 0.000 \\
\hline Assertive 6 & 25.196 & 0.000 \\
\hline \multicolumn{3}{|c|}{ Statement of Value Added (DVA) } \\
\hline Assertive 7 & 29.776 & 0.000 \\
\hline Assertive 8 & 21.461 & 0.000 \\
\hline Assertive 9 & 26.245 & 0.000 \\
\hline \multicolumn{3}{|c|}{ Statement of Retained Earnings (DLPA) } \\
\hline Assertive 10 & 15.920 & 0.000 \\
\hline Assertive 11 & 25.389 & 0.000 \\
\hline \multicolumn{3}{|c|}{ Cash Flow Statement (DFC) } \\
\hline Assertive 12 & 14.083 & 0.000 \\
\hline Assertive 13 & 24.100 & 0.000 \\
\hline Assertive 14 & 25.664 & 0.000 \\
\hline \multicolumn{3}{|c|}{ Statement of Changes in Net Equity (DMPL) } \\
\hline Assertive 15 & 27.631 & 0.000 \\
\hline Assertive 16 & 25.324 & 0.000 \\
\hline
\end{tabular}

Note: Own Elaboration (2015).

the sample followed a normal distribution. Thus, we opted for the Kolmogorov-Smirnov test due to sample has surpassed 20 answers. Then there was a Descriptive Statistics with chi-square test in which the data were organized in a frequency distribution. Finally, the data passed through the Hypothesis Test t-Student, whose aim was to reject or not the null hypothesis.

Through the normality Kolmogorov-Smirnov test was concluded that the sample tends not normal. Thus, the null hypothesis of normal distribution of data was rejected. In the descriptive analysis, we found the high frequencies of assertions that were answered incorrectly, indicative of the small field of graduates in Accounting in Bahia.

In turn, the Student $t$ test Hypothesis corroborated value of Sig. 0\%, rejecting the null hypothesis. Therefore, it was concluded that the graduates in Accounting in the State of Bahia not dominate the changes in the Financial Statements after the term of Law No. 11,638 (Brazil, 2007) and 11,941 (Brazil, 2009).

The negative result pointed this research as to the field of the Bahian students is worrying. This is critical because the Accounting professional future master the structure and the elements of each Accounting statement. Therefore, it is believed that this study may contribute to the teaching of Accounting in Bahia to demonstrate the reality of the lack of student field about the current financial statements, probably a reality that extends nationwide.

Therefore, it is appropriate to charge the HEIs greater commitment in the process of formation of Accounting professionals at the undergraduate level, so having knowledge level aligned to market requirements, as well as the ability in the areas in which they operate. As regards the limitation of the study, records the difficulty in obtaining the answers that formed the sample because few were willing to disclose IES of the survey questionnaire, 
and these IES, the few were the students who answered the study. Therefore, came in contact with each Coordinator of the Accounting course of campuses participants through phone call seeking support towards the completion of the study, which favored its completion.

Finally, it is mentioned that further studies may be developed using the search tool built for this search. One would compare the results obtained in other regions with the achieved in this research and examine whether the results are different or similar to Bahia reality is the Bahian students.

\section{References}

Barbetta, P. A., Reis, M. M., \& Bornia, A. C. (2010). Statistics for Engineering and Computer courses (3ª ed.). São Paulo: Atlas.

Berns, J. C. G., \& Flach, L. (2013). Statement of Value Added: Sector Analysis of the Allocation of Wealth in the New Market Companies after the Financial Crisis, 2008. VII Congresso ANPCONT (Associação Nacional de Programas de Pós-Graduaçãoem Ciências Contábeis).

Brazil (1976). Law nº 6.404 de 15 de dezembro de 1976. Legislation, Brasília, DF.

http://www.planalto.gov.br/ccivil_03/leis/16404consol.htm

Brazil (2007). Law no 11.638 de 28 de dezembro de 2007. Legislation, Brasília, DF. http://www.planalto.gov.br/ccivil_03/_ato20072010/2007/lei/l11638.htm

Brazil (2009). Law n 11.941 de 27 de may de 2009. Legislation, Brasília, DF. http://www.receita.fazenda.gov.br/Legislacao/leis/2009/lei11941.htm

Brazil (2004). Resolution CNE/CES n 6 of 10, March 2004. Legislation, Brasília, DF. http://portal.mec.gov.br/cne/arquivos/pdf/rces06_04.pdf

Callegari-Jacques, S. M. (2003).Biostatistics: Principles and Applications. Porto Alegre: Artmed.

Cardoso, R. L. et al. (2009). Regulation of Accounting and Accounting Regulation: Theory and Analysis of Law $n^{\circ}$ 11.638/07. Revista de Administração Pública, 43, 1-17. http://www.scielo.br/scielo.php?script=sci arttext\&pid=S0034-76122009000400003

Conselho Federal de Contabilidade (2009). Content National proposal for the course in Accounting. In J. DominguesCarneiro et al. (Coordenador), Fundação Brasileira de Contabilidade ( $2^{\mathrm{a}}$ ed., p. 187). Brasília. http://portalcfc.org.br/wordpress/wp-content/uploads/2013/01/proposta.pdf

Cunha, V. A., \& Lima, R. A. (2011). Changes of Law 11,638 (BRAZIL, 2007) in the Balance Sheet of publicly traded companies. XV Encontro Latino Americano de Iniciação Científica e XI Encontro Latino Americano de Pós-Graduação - Universidade do Vale do Paraíba, São José dos Campos. http://www.inicepg.univap.br/cd/INIC_2011/anais/arquivos/0215_0454_02.pdf

Cunha, J. V. A., da Ribeiro, M. de S., \& Santos, A. dos. (2005). The Statement of Value Added as Wealth Distribution Measuring Instrument. Revista Contabilidade Finanças, 16, 7-23.

Espejo, M. M. S. B. et al. (2010). Empirical Evidence of Teaching in the Course of Accounting: An Analysis of the Responses to Changes from Law 11,638 (BRAZIL, 2007). Revista de Contabilidade do Mestrado em Ciências Contábeis da UERJ, 15, 22-39.

Ferreira, R. J. (2009). Advanced Accounting and Intermediate (3 ${ }^{\mathrm{a}}$ ed.). Rio de Janeiro: Ferreira.

Gil, A. C. (2002). Como ElaborarProjetos de Pesquisa (4ª ed.). São Paulo: Atlas.

Iudícibus, S. de. (2007). Análise de Balanços (8 ${ }^{\mathrm{a}}$ ed.). São Paulo: Atlas.

Lakatos, E. M., \& Marconi, M. de A. (1992). Methodology of Scientific Work: Basic Procedures, Library Research, Design and Report, Publications and Scientific Papers (4 ${ }^{\mathrm{a}}$ ed.). São Paulo: Atlas.

Lima Filho, R. N., \& Bruni, A. L. (2012). Perception of Graduates in Accounting in Salvador (BA) on Relevant Concepts of Accounting Theory. Revista de Educação e Pesquisa em Contabilidade (REPeC), 6, 187-203.

Marion, J. C. (2009). Business Accounting (15º ed.). São Paulo: Atlas.

Peleias, I. R. et al. (2006). Didactic Teaching Accounting: Applicable to Other Colleges. São Paulo: Saraiva.

Raupp, F. M., \& Beuren, I. M. (2013). Methodology Applied Research to Social Sciences. In: I. M. Beuren (Org.), How to Prepare Monographic Work in Accountancy: Theory and Practice ( $3^{\mathrm{a}}$ ed., pp. 76-97). $8^{\mathrm{a}}$ reimpressão, São Paulo: Atlas.

Ribeiro, O. M. (2009). Structure and Easy Balance Sheet Analysis (8 ${ }^{\mathrm{a}}$ ed.). São Paulo: Saraiva.

Santos, D. G. dos et al. (2014). Education in Accounting and Its Relationship with the Labour Market: The Students’ Perception of Accounting of a Federal Institution of Higher Education. XI Congresso USP Iniciação Científicaem Contabilidade.

Velter, F., \& Missagia, L. R. (2007). Accounting Manual. Rio de Janeiro: Elsevier. 


\section{Appendix}

Balance Sheet-BP

A1. Both in public companies as in large companies, Profits are intended for the account: earnings and accumulated losses.

o True

o False

o I do not know the answer

O Do not studied this demonstration

A2. In the current structure of BP, the non-current assets is divided into three: Investments, Assets and Intangible Assets.

o True

o False

o I do not know the answer

o Do not studied this demonstration

A3. After the New Corporation Law, Net Equity is now composed of six subgroups: Social Capital, Capital Reserves, Valuation Adjustments, Profit Reserve, Treasury Stock and accumulated losses.

o True

o False

o I do not know the answer

o Do not studied this demonstration

The Income Statement-DRE

A4. Under the law, the DRE shall specify the gross revenue from sales and services, sales deductions, the obtained rebates and taxes payable.

o True

o False

o I do not know the answer

o Do not studied this demonstration

A5. The DRE should contain some items, according to legal requirements. Adjustments from the Previous not part of the DRE.

o True

o False

o I do not know the answer

o Do not studied this demonstration

A6. In thecalculation of net sales, in theincomestatement, thevalues of thefollowing are computed: thedirect sales tax, thegoodssold of returns and rebates on sales.

o True

o False

o I do not know the answer

o Do not studied this demonstration

Statement of Value Added - DVA

A7. The DVA is the Accounting Statement that aims to inform the value of the wealth created by the company and the form of distribution.

o True

o False

o I do not know the answer

o Do not studied this demonstration

A8. The results of the equity, financial revenues and revenues from rents are items that make up the value added liquid in the DVA.

o True

o False

o I do not know the answer

o Do not studied this demonstration 
A9. In DVA, expenditure on rent, the electricity consumed in the period and the positive equity in subsidiaries are shown, respectively, as a third of purchased inputs; return on capital from third parties and value added received in transfer.
o True
o False
o I do not know the answer
o Do not studied this demonstration
Profit \& Losses-DLPA

A10. If a company develop and publish the Statement of Changes in Equity, may include in this document the Statement of Profit and Losses.

o True

o False

o I do not know the answer

o Do not studied this demonstration

A11. The record of theloss of goodsfor resale reduce thevalue of net sales in DLPA. The True

o True

o False

o I do not know the answer

o Do not studied this demonstration

Cash Flows-DFC

A12. According to Law 11,638 / 07, the DFC will indicate the changes in cash and cash equivalents, being segregated in a maximum of three streams: I) of operations; II) funding; and III) of investments.

o True

o False

o I do not know the answer

o Do not studied this demonstration

A13. With the modifications promoted by corporate legislation and has replaced the Funds by DFC, but this is only mandatory for public companies with net worth of US \$ 2 million at the reporting date.

o True

o False

o I do not know the answer

o Do not studied this demonstration

A14. The DFC has two methods: direct and indirect. The first considers the inputs and outputs to the corresponding gross operations, and the second is composed of the present balance in the income statement.

o True

o False

o I do not know the answer

o Do not studied this demonstration

Statement of Changes in Shareholders' Equity-DMPL

A15. In DMPL is evidenced the allocation of net profit of the company earned in the year.

o True

o False

o I do not know the answer

o Do not studied this demonstration

A16. Publiccompaniesshall, in additiontothemandatorystatements, DMPL instead of DLPA.

o True

o False

o I do not know the answer

Do not studied this demonstration 